DOI: https://doi.org/10.24127/ajpm.v10i4.4367

\title{
PENGEMBANGAN PERANGKAT PEMBELAJARAN BERBASIS PROBLEM BASED LEARNING (PBL) UNTUK MENINGKATKAN KEMAMPUAN PEMECAHAN MASALAH
}

\author{
Dwi Ratih Listini Yusri ${ }^{1}$, Dony Permana ${ }^{2}$, I Made Arnawa ${ }^{3}$ \\ ${ }^{1,2}$ Pascasarjana UNP, Padang, Indonesia \\ ${ }^{3}$ Staff Pengajar Pascasarjana FMIPA UNAND, Padang, Indonesia \\ *Corresponding author. \\ Email: $\underline{\text { dwiratih.listianiyusri@gmail.com }}^{1)}$
}

Received 30 October 2021; Received in revised form 02 December 2021; Accepted 28 December 2021

\begin{abstract}
Abstrak
Kemampuan pemecahan masalah merupakan kemampuan esensial yang harus dimiliki peserta didik. Masalah dalam matematika merupakan persoalan tidak rutin dan belum ada metode untuk menyelesaikannya. Pentingnya kemampuan pemecahan masalah diberikan kepada peserta didik agar peserta didik mampu menyelesaikan masalah matematika, mampu memberikan kemampuan penalaran logis, sistematis, kritis dan terbuka dalam kehidupan sehari-hari. Penelitian ini bertujuan untuk menghasilkan perangkat pembelajaran dengan menggunakan model pembelajaran problem based learning (PBL) berupa RPP dan LKPD untuk meningkatkan kemampuan pemecahan masalah matematis peserta didik yang valid dan praktik. Penelitian ini mengembangkan perangkat pembelajaran berupa rancangan pelaksanaan pembelajaran (RPP) dan lembar kerja siswa (LKPD) dengan menggunakan model pengembangan Plomp. Model pengembangan Plomp terdiri dari fase investivigasi awal, fase pengembangan atau pembuatan prototype, dan fase penilaian. Penelitian ini juga menggunakan evaluasi formatif yaitu evaluasi sendiri, tinjauan ahli, evaluasi satu-satu, evaluasi kelompok kecil dan uji coba kelompok kecil. Subjek penelitian ini adalah peserta didik kelas XI SMAN 1 Lengayang. Hasil penelitian menunjukkan bahwa perangkat pembelajaran berbasis problem based learning(PBL) yang dikembangkan berupa RPP dan LKPD untuk meningkatkan kemampuan pemecahan masalah matematis yang valid dan praktis. Valid karena valid dari aspek isi dan konstruk dengan hasil validasi RPP diperoleh 3,3 dengan kategori valid dan LKPD diperoleh 3,47 dengan kategori sangat valid. Praktis karena mudah digunakan dan dipahami, efisien, menarik. Hasil praktikalitas RPP diperoleh 89,29\% dengan kategori sangat praktis dan LKPD diperoleh 90,32\% dengan kategori sangat praktis.
\end{abstract}

Kata kunci: Kemampuan pemecahan masalah; perangkat pembelajaran; problem based learning (PBL).

\begin{abstract}
Problem solving ability is an essential ability that must be possessed by students. Problems in mathematics are non-routine problems and there is no method to solve them. The importance of problem solving skills is given to students so that students are able to solve mathematical problems, are able to provide logical, systematic, critical and open reasoning abilities in everyday life. This study aims to produce learning tools using problem based learning (PBL) learning models in the form of RPP and LKPD to improve students' mathematical problem solving abilities that are valid and practical. This study develops learning tools in the form of lesson plans (RPP) and student worksheets (LKPD) using the Plomp development model. The Plomp development model consists of an initial investigation phase, a development or prototyping phase, and an assessment phase. This study also uses formative evaluation, namely self-evaluation, expert review, one-on-one evaluation, small group evaluation and small group trial. The subjects of this study were students of class XI SMAN 1 Lengayang. The results showed that problem-based learning (PBL) tools were developed in the form of RPP and LKPD to improve valid and practical mathematical problem solving skills. Valid because it is valid from the aspect of content and construct with the results of RPP validation obtained 3.3 with valid category and LKPD obtained 3.47 with very valid category. Practical because it is easy to use and understand, efficient, attractive. The results of the practicality of the lesson plans were $89.29 \%$ in the very practical category and $90.32 \%$ in the LKPD in the very practical category.
\end{abstract}

Keywords: Problem solving skills; learning tools; problem based learning (PBL).

This is an open access article under the Creative Commons Attribution 4.0 International License 


\section{PENDAHULUAN}

Perkembangan zaman yang terjadi secara terus menerus membuat standar pendidikan nasional juga ikut berubah. Perubahan ini berdampak pada kurikulum 2013, dimana mulai menerapkan pembelajaran yang berorientasi pada pada pembelajaran abad 21. Menurut (Asmar et al., 2019) (Qudrat \& Aji, 2019), mengatakan pembelajaran abad 21 memberikan kecakapan kepada peserta didik dalam kemampuan 4C yang meliputi: 1) Communication, 2) Collaboration, 3) Critical thinking and Problem Solving, 4) Creativity and innovation. Salah satu cirinya adalah menuntut peserta didik agar memiliki kemampuan pemecahan masalah (Fitri $\&$ Yuanita, 2020). Menurut (Sugiyarti et al., 2018), penerapan konsep 4C dalam pembelajaran memberikan dampak yang sangat besar bagi peserta didik untuk menghadapi tantangan abad 21. Berdasarkan tujuan pembelajaran dalam Permendikbud No.58 Tahun 2014, salah satu kemampuan yang harus dimiliki peserta didik dalam belajar matematika adalah kemampuan pemecahan masalah (Nasution et al., 2018)

Kemampuan pemecahan masalah merupakan keterampilan yang mengasah peserta didik untuk secara akurat mengidentifikasi data, membuat model matematika, memilih dan menerapkan strategi, menginterpretasikan hasil untuk memverifikasi kebenaran hasil atau jawaban yang diperoleh (Permana \& Afrilia, 2019). Pentingnya kemampuan pemecahan masalah diberikan kepada peserta didik agar peserta didik mampu menyelesaikan masalah matematika, mampu memberikan kemampuan penalaran logis, sistematis, kritis dan terbuka dalam kehidupan sehari-hari (Akhter et al., 2015), (Yustianingsih \& Syarifuddin, 2017). Kurangnya kemampuan pemecahan masalah disebabkan guru kurang melibatkan peserta didik ke dalam masalah yang menantang proses berfikir (Lambert \& Sugita, 2016).

Pada pencapaian PISA 2018, Indonesia berada pada kuadran low performance dengan high equity. Indonesia peringkat 72 dari 79 negara dan mendapat 379 poin. Berdasarkan TIMSS 2015, Indonesia memperoleh 397 skor dari rata-rata skor internasional yaitu 500 sehingga berada pada peringkat 44 dari 49 negara. Pada penelitian (Sariningsih \& Purwasih, 2017) menunjukkan kemampuan pemecahan masalah matematis masih dalam kriteria rendah dari 389 siswa. Hal ini karena, peserta didik kurang memahami soal yang diberikan guru, peserta didik belum terlatih dalam memodelkan matematika dan kurang teliti dalam menyelesaikannya.

Berdasarkan hasil wawancara yang dilakukan dengan peserta didik dan guru SMAN 1 Lengayang, didapatkan bahwa sumber belajar peserta didik masih menggunakan LKPD dari penerbit yang memuat kumpulan materi dan contoh soal. Guru menginginkan bentuk LKPD yang memuat soal-soal, terutama soal-soal yang bervariasi. Agar bisa meningkatkan pemecahan masalah matematis peserta didik. Pada saat guru memberikan soal dalam berbentuk soal cerita, peserta didik kurang mampu dalam menyelesaikannya. Hal ini juga didukung dengan hasil tes awal kemampuan pemecahan masalah, dimana diperoleh hanya beberapa orang saja yang dapat menjawab. Untuk indikator memahami masalah menjawab 49.2\%, merencanakan penyelesaian masalah menjawab $42.5 \%$, indikator melaksanakan $44.2 \%$ dan memeriksa kembali hanya $4.2 \%$. 
Berdasarkan permasalahan yang dihadapi tersebut, untuk meningkatkan kemampuan pemecahan masalah peserta didik, guru harus merancang dan mempersiapkan proses pembelajaran dengan baik yang salah satunya dimulai dari perangkat pembelajaran. Perangkat yang digunakan berupa RPP dan LKPD dengan menggunakan model atau pendekatan yang dapat menunjang kemampuan pemecahan masalah matematis. Salah satu model pembelajaran yang diterapkan untuk mengimplementasikan pendekatan saintifik berdasarkan (Kemendikbud, 2018) adalah model pembelajaran berbasis problem based learning (PBL).

PBL adalah proses pembelajaran yang memulai pembelajaran dengan memberikan masalah yang berhungan dengan kehidupan sehari-hari. Perangkat pembelajaran berbasis PBL adalah perangkat yang menggunakan masalah sebagai langkah awal dalam mengumpulkan dan mengintegrasikan pengetahuan baru. Penggunaan masalah-masalah dalam proses pembelajaran akan menjadikan pembelajaran tersebut lebih bermakna.

Dalam penelitian yang dilakukan oleh (Anggiana \& Pasundan, 2019), (Amalia \& Lubis, 2019), (P \& Wahyuni, 2018) menjelaskan bahwa kemampuan pemecahan masalah peserta didik dengan menggunakan model pembelajaran Problem Based Learning dengan itu dapat membantu peserta didik dalam memecahkan masalah yang diberikan dikaitkan dalam kehidupan sehari-hari dan didukung dengan model pembelajaran Problem Based Learning yang dapat membantu dalam menyelesaikan soal kemampuan pemecahan masalah.

Oleh karena itu, dikembangkanlah perangkat pembelajaran berbasis PBL berupa rancangan pelaksanaan pembelajaran (RPP) dan lembar kerja peserta didik (LKPD), agar dapat memudahkan peserta didik untuk memahami materi dalam proses pembelajaran. Perangkat pembelajaran diharapkan juga dapat meningkatkan kemampuan pemecahan masalah peserta didik.

\section{METODE PENELITIAN}

Jenis penelitian ini adalah penelitian pengembangan dengan menggunakan model Plomp. Model Plomp terdiri dari fase investigasi awal (preliminary research), fase pengembangan atau pembuatan prototipe (prototyping phase), dan fase penilaian (assessment phase) (Plomp, 2010). Fase investigasi awal (preliminary research) terdiri dari analisis kebutuhan, analisis kurikulum, analisis konsep. Pada pembuatan prototipe (prototyping stage) dilakukan evaluasi formatif. Fase pengembangan atau pembuatan prototype (prototyping stage) terdiri atas evaluasi diri sendiri (self evaluation); expert review; yaitu evaluation one to one; evaluation small group, dan Pada fase penilaian (assessment stage).

Penelitan ini dilakukan pada kelas XI SMAN 1 Lengayang. Data penelitian dikumpulkan melalui lembar self evaluation, lembar validasi, lembar observasi dan pedoman wawancara, lembar angket respon guru dan peserta didik, lembar observasi keterlaksanaan RPP, dan tes kemampuan pemecahan masalah peserta didik. Kemudian divalidasi oleh validator yang merupakan para ahli dalam bidang matematika, teknologi dan bahasa.

Hasil validasi dari validator terhadap aspek-aspek yang dinilai disajikan dalam bentuk tabel. Kemudian dicari rata-rata skor dengan menggunakan rumus berikut: 
DOI: https://doi.org/10.24127/ajpm.v10i4.4367

Keterangan:

$$
R=\frac{\sum_{i=1}^{n} V_{i}}{n}
$$

$R=$ rata-rata hasil penilaian validator

$V_{i}=$ skor hasil penilaian validator ke-i

$n$ = banyaknya validator yang menilai

Kriteria untuk mendapatkan
tingkat kevalidan
pembelajaran menggunakan kriteria
pada Tabel 1.

Tabel 1. Kriteria validitas

\begin{tabular}{cc}
\hline Rata-rata & Kriteria \\
\hline $\mathrm{R}>3,4$ & Sangat Valid \\
$2,8<\mathrm{R} \leq 3,4$ & Valid \\
$2,2<\mathrm{R} \leq 2,8$ & Cukup Valid \\
$1,6 \mathrm{R} \leq 2,2$ & Kurang Valid \\
$1<\mathrm{R} \leq 1,6$ & Tidak Valid \\
\hline
\end{tabular}

Pada penelitian ini, perangkat yang dikembangkan minimal harus memenuhi kriteria valid. Selanjutnya untuk uji praktikalitas perangkat dilakukan dengan menggunakan instrumen angket praktikalitas atau kepraktisan. Hasil dari angket kemudian dianalisis dengan menggunakan rumus berikut (Purwanto, 2012):

$$
P=\frac{R}{S M} \times 100 \%
$$

Dengan P : nilai kepraktisan; R :skor yang diperoleh; dan SM :skor maksimum.

Setelah diperoleh nilai $P$, kemudian nilai tersebut diklasifikasikan sesuai dengan Tabel 2.

Tabel 2. Kriteria Kepraktisan

\begin{tabular}{ll}
\hline $\begin{array}{l}\text { Nilai Kepraktisan } \\
(\%)\end{array}$ & Kriteria \\
\hline $85 \leq \mathrm{P}<100$ & Sangat Praktis \\
$70 \leq \mathrm{P}<85$ & Praktis \\
$55 \leq \mathrm{P}<70$ & Cukup Praktis \\
$40 \leq \mathrm{P}<55$ & Kurang Praktis \\
$25 \leq \mathrm{P}<40$ & Tidak Praktis \\
\hline
\end{tabular}

Sumber: Modifikasi (Purwanto, 2012)
Pada penelitian ini, perangkat pembelajaran yang dikembangkan dikatakan sudah memenuhi kriteria minimum praktikalitas jika memenuhi kriteria minimal praktis (pada Tabel 2).

\section{HASIL DAN PEMBAHASAN}

1. Fase Investigasi Awal

Kegiatan pada fase investigasi awal dimulai dengan analisis kebutuhan, analisis kurikulum, analisis peserta didik dan analisis konsep. Uraian hasil fase investigasi awal yaitu:

a. Analisis Kebutuhan

Pada tahap analisis kebutuhan dilakukan pengumpulan informasi mengenai permasalahan yang terdapat dalam pembelajaran matematika. Pengumpulan informasi dilakukan dengan mewawancarai beberapa orang peserta didik dan pendidik pada SMAN 1 Lengayang. Serta mengobservasi perangkat pembelajaran yang ada di lapangan dan kegiatan pembelajaran.

Informasi yang diambil terkait dengan proses pembelajaran yang berlangsung baik dari aspek tujuan pembelajaran yang telah ditetapkan oleh kurikulum. Mendapatkan informasi kondisi awal kemampuan pemecahan masalah matematis peserta didik dilakukan dengan cara memberikan soal tes kemampuan pemecahan masalah matematis sesuai materi yang sudah dipelajari. Dilihat dari tes kemampuan pemecahan masalah matematis yang diberikan kepada beberapa peserta didik kelas XI SMAN 1 Lengayang, diperoleh dari peserta didik tersebut hanya beberapa orang peserta didik yang bisa menyelesaikan soal tersebut. Terlihat bahwa peserta didik belum mampu menyelesaikan soal kemampuan pemecahan masalah matematis.

Hasil wawancara dengan pendidik diperolah bahwa pendidik telah berupaya menerapkan model-model 
pembelajaran yang dapat memotivasi dan mengaktifkan peserta didik dalam proses pembelajaran. Namun tujuan pembelajaran masih belum tercapai karena masih rendahnya kemampuan pemecahan masalah. Beberapa kendala yang ditemui peserta didik terlihat kebingungan dalam pemecahan masalah yang dalam bentuk soal cerita. Hasil analisis angket mengungkapkan bahwa bahan ajar yang diinginkan oleh peserta didik antara lain mengenai warna dan ukuran bahan ajar. Selain itu dari tes awal kemampuan pemecahan masalah matematis peserta didik terlihat masih sedikit persentase peserta didik yang bisa mengerjakan soal pemecahan masalah. Hal ini menunjukkan bahwa kemampuan pemecahan masalah peserta didik masih belum optimal.

\section{b. Analisis Kurikulum}

Pada tahap ini dilakukan telaah terhadap Kurikulum 2013 untuk mata pelajaran Matematika kelas XI SMA pada semester I. Analisis ini diperlukan untuk mempelajari cakupan materi, tujuan pembelajaran, pemilihan pendekatan dan model pembelajaran yang sesuai sebagai landasan untuk mengembangkan perangkat pembelajaran yang diharapkan. Hasil analisis kurikulum pada semester I kelas XI SMA kesemua urutan materi tersebut sudah sesuai dengan yang seharusnya.

Hasil analisis kurikulum pada semester I kelas XI SMAN 1 Lengayang, dimana kesesuain KI dengan KD pada kurikulum sudah sesuai. Kesesuain KD dengan indikator pembelajaran masih belum sesuai begitu juga dengan kesesuain indikator dengan tujuan pembelajaran. Kesesuian pembelajaran dengan karakteristik peserta didik belum juga sesuai, dimana terdapat 4 KI dimana KI-1 berkaitan dengan sikap spiritual, KI-2 berkaitan dengan sikap sosial, KI-3 berkaitan dengan pengetahuan, dan KI-4 memuat keterampilan matematis yang harus dikuasai peserta didik.

\section{c. Analisis Peserta Didik}

Analisis peserta didik bertujuan untuk mengetahui kualitas perorangan yang dapat dijadikan petunjuk dalam merancang perangkat pembelajaran. Fokus kegiatan yang dilakukan pada menganalisis peserta didik adalah bagaimana karakteristik peserta didik yang meliputi level berpikir, kecenderungan belajar, bagaimana pengetahuan peserta didik untuk menggunakan perangkat pembelajaran yang dirancang. Analisis dilakukan pada peserta didik kelas XI SMAN 1 Lengayang dengan cara penyebaran angket.

Hasil angket peserta didik menunjukkan beberapa hal. Pertama, lebih banyak peserta didik yang lebih menyukai kegiatan pembelajaran secara berkelompok. Hal ini menunjukkan bahwa peserta didik lebih suka melakukan suatu aktivitas secara bersama-sama.

Poin kedua, apabila mengalami kesulitan atau tidak memahami materi, sebagian besar peserta didik lebih suka bertanya kepada temannya. Ketiga, peserta didik juga memerlukan atau membutuhkan sumber belajar berupa LKPD menarik yang warna dominan biru yang berisi cakupan materi, contoh soal yang berhubungan dengan kehidupan nyata sesuai dengan lingkungannya sehingga peserta didik dapat memahami pelajaran secara mandiri.

Poin Keempat, peserta didik menghadirkan kegiatan diskusi untuk menjawab pertanyaan terkait materi, agar peserta didik mendapatkan pengalaman belajar yang memberikan kesempatan untuk menggunakan 
kemampuan yang dimilikinya dalam memahami materi pelajaran, sehingga yang didapatkan dalam proses pembelajaran akan bertahan lama. Poin terakhir, atau kellima adalah peserta didik cenderung mempresentasikan hasil diskusinya di depan kelas sehingga hal ini dapat membuat peserta didik mampu mengkomunikasikan hasil diskusinya.

\section{d. Analisis Konsep}

Analisis konsep merupakan identifikasi materi-materi esensial yang akan dibahas pada pembelajaran kemudian menyusunnya secara sistematis dengan mengaitkan suatu konsep dengan konsep lain yang relevan sehingga membentuk suatu konsep. Analisis konsep bertujuan untuk mengidentifikasi fakta, konsep, prinsip, dan prosedur yang harus dikuasai peserta didik. Selanjutnya hasil dari analisis ini digunakan sebagai patokan untuk menyusun perangkat pembelajaran berbasis model Problem Based Learning. Hasil analisis konsep dilihat dari materi kelas XI SMA semester I yaitu, Induksi Matematika, Program Linear, Matriks, Determinan, dan Transformasi.

2. Fase Pengembangan atau Pembuatan Prototipe

a. Merancang Perangkat Pembelajaran Merancang perangkat pembelajaran matematika berbasis model Problem Based Learning berdasarkan analisis pada fase investigasi awal. Hasil perancangan ini akan menghasil-kan prototipe 1 . Perangkat pembelajaran dirancang mengacu pada karakteristik pembelajaran PBL. Berikut uraian perangkat pembelajaran berbasis model PBL.

\section{1) Perancangan RPP}

RPP dirancang sebagai pedoman bagi guru dalam melaksanakan proses pembelajaran. RPP dirancang secara sistematis sesuai dengan pedoman pada Permendikbud No. 22 Tahun 2016. RPP berfungsi sebagai pedoman bagi guru dalam menyampaikan materi pembelajaran. Kegiatan pembelajaran yang disajikan dalam RPP mengacu kepada pembelajaran berbasis model PBL yang terintegrasi dalam LKPD yang juga berbasis model PBL. Penyajian RPP tersebut terdiri dari identitas RPP, kompetensi inti, kompetensi dasar, indikator, tujuan pembelajaran, materi ajar, alokasi waktu, metode pembelajaran, kegiatan pembelajaran, sumber belajar dan penilaian hampir sama dengan RPP pada umumnya. Komponen RPP yang menjadi ciri khas dari RPP berbasis model PBL dapat dicermati pada langkah-langkah kegiatan pembelajaran. Kegiatan inti pada RPP berdasarkan sintaks pembelajaran berbasis model PBL. Ada 5 langkah dalam model pembelajaran PBL yaitu: peserta didik diminta untuk mencari informasi dari masalah yang telah diberikan, mencari penyebab dari masalah, menganalis faktor-faktor penyebab masalah, merumuskan alternatif strategi untuk menyelesaikan masalah, memilih strategi yang akan digunakan dan melakukan penilaian untuk memperoleh hasil dari kegiatan yang dilakukan.

\section{2) Perancangan LKPD}

LKPD berbasis model PBL memiliki beberapa komponen yaitu judul, KD, petunjuk LKPD, tujuan pembelajaran, masalah, langkah kerja, dan latihan. LKPD memiliki soal-soal yang berhubungan langsung dengan 
peserta didik dan berkaitan dengan kehidupan di kabupaten Pesisir Selatan.

LKPD didesain dengan warna yang bervariasi dan cerah. LKPD diawali dengan menghadirkan pertanyaan-pertanyaan atau masalah yang bertujuan untuk membantu peserta didik untuk mengaitkan fenomena sekita Kabupaten Pesisir Selatan yang diamati dengan konsep yang akan dikonstruksi.

Selanjutnya untuk melatih kemampuan pemecahan masalah peserta didik mengidentifikasi unsurunsur yang diketahui, ditanyakan, dan kecukupan unsur yang diperlukan, merumuskan masalah, menyelesaikan masalah, penarikan kesimpulan dan memeriksa kembali hasil yang diperoleh. LKPD menggunakan bahasa yang sederhana dan komunikatif serta sesuai dengan tingkat pemecahan masalah peserta didik, sehingga penyajian materi pada LKPD dapat dipahami dengan baik. Pertanyaanpertanyaan dalam LKPD disusun dengan kalimat yang jelas sehingga mampu mengarahkan peserta didik mendapatkan jawaban yang diharapkan.

\section{b. Self evaluation}

Hasil rancangan perangkat pembelajaran pada tahap awal disebut prototype I. Prototype 1 merupakan hasil revisi dari self evaluation terhadap perangkat pembelajaran yang telah dikembangkan. Self evaluation disebut evaluasi yang dilakukan terhadap perangkat yang dilakukan sendiri. Kegiatan yang dilakukan dengan cara melihat kembali hasil rancangan perangkat dan memperbaiki kesalahankesalahan yang terlihat jelas pada perangkat tersebut. Kesalahan tersebut bisa berupa kesalahan pengetikan, penggunaan kata, istilah, tanda baca, dan penempatan gambar.
Secara umum, kesalahan dari LKPD dari lima materi pokok kesalahan yang sering muncul yaitu kesalahan pada pengetikan kata dan tanda baca, seperti penggunaan tanda titik untuk akhir kalimat. Pada LKPD terdapat kesalahan dalam pengetikan dan penggunaan spasi, seperti kata "dibawah ini' menjadi "di bawah ini". Selanjutnya, terdapat kesalahan dalam penggunaan tanda baca, seperti penggunaan tanda seru untuk kalimat perintah. Penggunaan tanda tanya pada kalimat tanya. Kesalahan lain yaitu tidak konsisten menggunakan kata "Ananda" sebagai sapaan kepada peserta didik.

Setelah dilakukan self evaluation, dilakukan revisi terhadap perangkat pembelajaran. Kemudian hasil prototype 1 dikonsultasikan dan didiskusikan dengan pakar atau ahli yang berkompeten untuk divalidasi.

c. Hasil Validasi Perangkat Pembelajaran oleh Para Ahli

Prototype 2 merupakan hasil revisi berdasarkan saran dari validator terhadap perangkat pembelajaran yang dikembangkan dan telah valid. Saran dari validator terhadap RPP dan LKPD yang dirancang akan dijadikan pedoman untuk melakukan revisi terhadap prototype 1. Perangkat pembelajaran matematika berbasis model Problem Based Learning divalidasi oleh 5 orang pakar, yaitu 3 orang dosen matematika, 1 orang dosen teknologi pendidikan, dan 1 orang dosen bahasa Indonesia. Hal ini dapat dilihat pada Tabel 3.

Tabel 3. Hasil validasi RPP

\begin{tabular}{llcl}
\hline No & $\begin{array}{c}\text { Aspek yang } \\
\text { Dinilai }\end{array}$ & $\begin{array}{c}\text { Rata-rata } \\
\text { Validitas }\end{array}$ & Kriteria \\
\hline 1 & Isi & 3,3 & Valid \\
2 & Bahasa & 3,2 & Valid \\
\hline Nilai Validitas RPP & $\mathbf{3 , 3}$ & Valid \\
\hline
\end{tabular}


Selama proses validasi terdapat beberapa revisi yang disarankan oleh para validator. Nilai validitas RPP secara keseluruhan adalah 3,3 dengan kategori valid. Dengan demikian dapat disimpulkan bahwa aspek komponen RPP berbasis model PBL sudah valid. Hal ini dapat dilihat pada Tabel 4.

Tabel 4. Hasil validasi LKPD dengan pakar pendidikan matematika

\begin{tabular}{llcc}
\hline No & $\begin{array}{c}\text { Aspek yang } \\
\text { Dinilai }\end{array}$ & $\begin{array}{c}\text { Rata-rata } \\
\text { Validitas }\end{array}$ & Kriteria \\
\hline 1 & Penyajian & 3,50 & Sangat Valid \\
2 & Kelayakan Isi & 3,19 & Valid \\
\hline Nilai & Validitas LKPD & $\mathbf{3 , 3 7}$ & Valid \\
\hline
\end{tabular}

Pada LKPD aspek yang diamati adalah aspek dikdatik atau penyajian dan aspek kelayakan isi yang divalidasi oleh 3 validator. Berdasarkan Tabel 4, terlihat bahwa baik dari segi penyajian maupun kelayakan isi, LKPD yang dikembangkan sudah memenuhi kriteria valid.

Validasi LKPD terhadap aspek kebahasaan dilakukan oleh 1 orang dosen bahasa Indonesia . Nilai validasi aspek kebahasaan terhadap LKPD adalah 3,5 dengan kriteria sangat valid. Hasil validasi menggambarkan bahwa penggunaan kalimat pada LKPD telah sesuai dengan kaidah bahasa Indonesia yang baik. Kalimat yang digunakan mampu melibatkan kemampuan berfikir logis peserta didik karena telah disesuaikan dengan tingkat bahasa komunikasi peserta didik. Dengan demikian dapat disimpulkan bahwa LKPD telah valid dari aspek kebahasaan.

Validasi LKPD terhadap aspek kegrafikan atau tampilan dilakukan oleh 1 orang dosen teknologi pendidikan. Hasil validasi aspek kegrafikan terhadap LKPD adalah 3,29 dengan kriteria valid. Dengan demikian dapat disimpulkan bahwa LKPD telah valid dari aspek kegrafikan atau tampilan. Berdasarkan semua penilaian validitas LKPD, diperoleh nilai akhir 3,47 dan memenuhi kategori sangat valid. Dengan demikian dapat disimpulkan LKPD berbasis model PBL sudah valid.

\section{d. One to one evaluation}

Hasil revisi prototype I yaitu prototype II, dilakukan uji coba terhadap 3 orang peserta didik untuk mencoba mengerjakan LKPD yang telah dinyatakan valid oleh ahli. Ketiga peserta didik tersebut berasal dari kelas XI SMAN 1 Lengayang yang memiliki kemampuan yang berbeda-beda, 1 dengan kemampuan tinggi, 1 dengan kemampuan sedang dan 1 dengan kemampuan sedang. Masing-masing peserta didik diminta untuk memperhatikan penyajian LKPD, mencoba mengerjakan LKPD sesuai pemahaman mereka terhadap permasalahan, gambar, perintah dan pertanyaan yang ada pada LKPD dan diminta untuk memberi komentar pada LKPD.

Evaluasi perorangan ini dilakukan pada 5 LKPD. Kegiatan yang dilakukan yaitu mengamati petunjuk yang sulit dipahami oleh peserta didik, mencatat tanggapan, saran, kalimat yang disajikan sulit dipahami serta pertanyaan peserta didik mengenai LKPD. Berdasarkan hasil observasi dan wawancara maka dilakukan revisi. Hasil praktikalitas LKPD pada One to One dapat dilihat pada Tabel 5.

Tabel 5. Hasil praktikalisasi LKPD peserta didik pada one to one

\begin{tabular}{clcl}
\hline No & $\begin{array}{c}\text { Aspek yang } \\
\text { Dinilai }\end{array}$ & $\begin{array}{c}\text { Rata-rata } \\
\text { Praktikalitas }\end{array}$ & Kriteria \\
\hline 1 & Penyajian & 82 & Praktis \\
2 & Kemudahan & 64 & Praktis \\
& Penggunaan & & \\
3 & Keterbacaan & 67 & Praktis \\
4 & Waktu & 83 & Praktis \\
\hline & Rata-rata & $\mathbf{7 3}$ & Praktis \\
\hline
\end{tabular}


DOI: https://doi.org/10.24127/ajpm.v10i4.4367

Praktiklitas LKPD pada One to One terhadap aspek penyajian, kemudahan penggunaan, keterbacaan dan waktu. Nilai praktikalitas LKPD secara keseluruhan adalah $73 \%$ dengan kategori praktis. Dengan demikian dapat disimpulkan LKPD berbasis model PBL sudah praktis.

\section{e. Small Group Evaluation}

Evaluasi kelompok kecil (small group evaluation) terhadap prototype III, dilakukan uji coba terhadap peserta didik kelas XI SMAN 1 Lengayang. Pada evaluasi kelompok kecil, peserta didik terdiri dari 6 orang peserta didik yang berasal dari kemampuan tinggi, sedang dan rendah. Enam peserta didik tersebut dibagi menjadi dua kelompok dengan kemampuan yang heterogen. Peserta didik tersebut diberikan LKPD yang telah valid dan telah praktis berdasarkan tahap evaluasi perorangan (one to one evaluation). Evaluasi kelompok kecil ini dilaksanakan sebanyak lima kali pertemuan.

Berdasarkan observasi dan wawancara yang dilakukan pada peserta didik didapatkan hasil bahwa untuk segi efisiensi waktu menurut peserta didik waktu untuk mengerjakan LKPD sudah cukup. Selanjutnya, pada segi implementasi, peserta didik mampu menggunakan LKPD dengan cukup mudah, meskipun masih ada timbul pertanyaan selama mengerjakan LKPD.

Segi penyajian LKPD sudah menarik dengan adanya permasalahan dalam kehidupan sehari-hari yang berhubungan langsung dengan peserta didik berkaitan kabupaten Pesisir Selatan, meskipun awalnya peserta didik merasa kesulitan karena jarang menyelesaikan soal cerita namun peserta didik terlihat antusias untuk mencobanya. Pada bagian desain pembelajaran menurut peserta didik strategi pembelajaran dengan menggunakan soal yang berhubungan dengan kehidupan sehari-hari sudah cukup menarik, pertanyaanpertanyaannya membantu peserta didik menyelesaikan permasalahan dan membuat kesimpulan. Kegiatankegiatan yang ada pada LKPD menarik, penyajian gambar serta ilustrasi pada LKPD memudahkan mereka untuk memahami konsep materi yang mereka pelajari.

Data kepraktisan LKPD berbasis model Problem Based Learning diperoleh dari angket respon peserta didik, angket respon guru serta observasi pelaksanaan pembelajaran. Angket praktikalitas diberikan kepada seluruh peserta didik pada saat melaksanakan evaluasi kelompok kecil. Angket diberikan kepada 6 peserta didik. Angket diberikan setelah proses pembelajaran menggunakan LKPD berbasis model Problem Based Learning selesai. Hasil dapat dilihat pada Tabel 6.

Tabel 6. Hasil praktikalitas LKPD respon peserta didik

\begin{tabular}{llcl}
\hline No & $\begin{array}{c}\text { Aspek yang } \\
\text { Dinilai }\end{array}$ & $\begin{array}{c}\text { Rata- } \\
\text { rata }\end{array}$ & Kriteria \\
\hline 1 & Penyajian & 89 & Sangat Praktis \\
2 & Kemudahan & 88 & Sangat Praktis \\
& Penggunaan & & \\
3 & Keterbacaan & 88 & Sangat Praktis \\
4 & Waktu & 92 & Sangat Praktis \\
\hline Nilai Praktikalitas & $\mathbf{8 8}$ & Sangat Praktis \\
LKPD & & \\
\hline
\end{tabular}

Rata-rata tingkat kepraktisan LKPD berbasis model Problem Based Learning menurut respon peserta didik adalah $88 \%$ yang berada pada kategori sangat praktis. Jadi, dapat disimpulkan bahwa LKPD berbasis model Problem Based Learning praktis menurut respon peserta didik. Hasil praktikalitas LKPD dari respon pendidik dapat dilihat pada Tabel 7. 
DOI: https://doi.org/10.24127/ajpm.v10i4.4367

Tabel 7. Hasil praktikalitas LKPD respon pendidik

\begin{tabular}{llcl}
\hline No & $\begin{array}{c}\text { Aspek yang } \\
\text { Dinilai }\end{array}$ & $\begin{array}{c}\text { Rata- } \\
\text { rata }\end{array}$ & Kriteria \\
\hline 1 & Penyajian & 88 & Sangat Praktis \\
2 & Kemudahan & 96 & Sangat Praktis \\
& Penggunaan & & \\
3 & Keterbacaan & 88 & Sangat Praktis \\
4 & Waktu & 92 & Sangat Praktis \\
\hline Nilai Praktikalitas & $\mathbf{9 2}$ & Sangat Praktis \\
LKPD & & \\
\hline
\end{tabular}

Rata-rata tingkat kepraktisan LKPD berbasis model Problem Based Learning menurut respon guru adalah 92\%. Jadi, dapat disimpulkan bahwa LKPD berbasis model Problem Based Learning sangat praktis menurut respon guru. Rata-rata tingkat kepraktisan pelaksanaan kegiatan pembelajaran berdasarkan RPP berbasis model Problem Based Learning adalah 89\%. Jadi, dapat disimpulkan bahwa perangkat pembelajaran berbasis model Problem Based Learning sangat praktis berdasarkan keterlaksanaan kegiatan pembelajaran.

Penelitian ini juga sejalan dengan penelitian yang telah dilakukan dengan mengembangkan perangkat pembelajaran menggunakan model pembelajaran PBL untuk meningkatkan kemampuan pemecahan masalah matematis peserta didik yang dilakukan oleh (Yustianingsih \& Syarifuddin, 2017), (Mariyam et al., 2018), (Sariningsih \& Purwasih, 2017), (Nessa et al., 2017) Pengembangan penelitian ini yang digunakan adalah mode Plomp yang terdiri dari tahap awal penelitian, tahap prototipe, dan tahap penilaian. Hasil penelitian menunjukkan bahwa PBL telah memenuhi kriteria yang valid dalam hal isi dan konstruksi. Peralatan pelajaran telah dianggap praktis dalam hal pelaksanaan dan efisiensi penggunaan waktu oleh pendidik dan siswa. Alat pelajaran juga efektif dalam hal proses penguasaan presentasi siswa belajar setelah menggunakan pembelajaran berbasis perangkat berbasis pembelajaran lebih besar dari sedangkan dalam hal hasil rata-rata siswa telah aktif dalam belajar.

Penelitian ini telah menghasilkan perangkat pembelajaran berbasis $\mathrm{PBL}$ untuk peserta didik kelas XI SMA pada materi Program Linear yang valid, praktis dan efektif dalam mencapai indikator kemampuan pemecahan masalah peserta didik. Perangkat pembelajaran berbasis PBL ini dapat dijadikan sumber belajar bagi peserta didik dalam pembelajaran matematika.

\section{KESIMPULAN DAN SARAN}

Berdasarkan hasil analisis data yang telah dilakukan dapat disimpulkan bahwa perangkat pembelajaran dengan menggunakan model pembelajaran problem based learning (PBL) berupa RPP dan LKPD untuk meningkatkan kemampuan pemecahan masalah matematis peserta didik kelas XI SMA yang valid dan praktis.

Berdasarkan penelitian yang telah dilaksanakan, maka dapat disarankan dapat melakukan pengembangan perangkat pembelajaran matematika menggunakan model problem based learning (PBL) kelas XI SMA berupa RPP dan LKPD pada materi matematika lainnya dan dapat digunakan dalam proses pembelajaran di sekolah.

\section{DAFTAR PUSTAKA}

Akhter, N., Akhtar, M., \& Abaidullah, M. (2015). The Perceptions of High School Mathematics Problem Solving Teaching Methods in Mathematics Education. 37(1), 55-77.

Amalia, P., \& Lubis, A. (2019). Development of Learning Materials Based on Problem Based Learning to Improve 
DOI: https://doi.org/10.24127/ajpm.v10i4.4367

Students Problem Solving Ability. Proceedings of The 4th Annual International Seminar on Transformative Education and Educational Leadership (AISTEEL), 197. http://digilib.unimed.ac.id/38773/ 2/full text.pdf

Anggiana, A. D., \& Pasundan, U. (2019). Implementasi Model Problem Based Learning ( $\mathrm{Pbl}$ ) Untuk Meningkatkan Kemampuan Pemecahan Masalah Matematis Siswa. 4, 56-69.

Asmar, A., Permana, D., Jamaan, E. Z., \& Amalita, N. (2019). Improving Mathematical Teachers Competency 21th Through Workshop Development of Mathematical Olympic Problems Based On High Order Thinking Skills In Smp Solok Selatan District. 2(2), 109-114.

Fitri, M., \& Yuanita, P. (2020). Pengembangan Perangkat Pembelajaran Matematika Terintegrasi Keterampilan Abad 21 Melalui Penerapan Model Problem Based Learning ( PBL ). 1, 77-85.

Kemendikbud. (2018). jdih.kemdikbud.go.id.

Lambert, R., \& Sugita, T. (2016). Increasing Engagement of Students with Learning Disabilities in Mathematical Problem-Solving and Discussion. 347-366.

https://doi.org/10.1111/14679604.12142

Mariyam, Citroresmi, N., \& Wahyuni, R. (2018). Pengembangan Kemampuan Pemecahan Masalah Matematis Siswa Pada Materi Pertidaksamaan Linier Satu Variabel Melalui Model Problem Based Learning Berbantuan
Modul. September, 66-73.

Nasution, M. ., Yerizon, \& Gusmiyanti, R. (2018). Students

Mathematical Problem-Solving Abilities Through The Application of Learning Models Problem Based Learning Students Mathematical Problem -Solving Abilities Through The Application of Learning Models Problem Based Learning. 3. https://doi.org/10.1088/1757$899 X / 335 / 1 / 012117$

Nessa, W., Hartono, Y., \& Hiltrimartin, C. (2017). Pengembangan Buku Siswa Materi Jarak pada Ruang Dimensi Tiga Berbasis Science, Technology, Engineering, and Mathematics (STEM) ProblemBased Learning di Kelas X. Jurnal Elemen, 3(1), 1. https://doi.org/10.29408/jel.v3i1.2 73

P, N. C., \& Wahyuni, R. (2018). Pengembangan Kemampuan Pemecahan Masalah Matematis Siswa Pada Materi Pertidaksamaan Linier Satu Variabel Melalui Model Problem Based Learning Berbantuan Modul. September, 66-73.

Purwanto, M. N. (2012). Prinsip-Prinsip dan Teknik Evaluasi Pengajaran, Bandung: PT. Remaja Rosdakarya.

Permana, D., \& Afrilia, C. (2019). Development of Mathematical Worksheet for Junior High School Based on Guided Discovery Oriented by. 7(10).

Plomp, T. (2010). Educational design research.

Qudrat, M., \& Aji, W. (2019). Jurnal Penelitian Teknologi Pendidikan http://jurnal.uns.ac.id/Teknodika. 17(02), 70-84. 
DOI: https://doi.org/10.24127/ajpm.v10i4.4367

Sariningsih, R., \& Purwasih, R. (2017). file:///E:/DATA P/bahan jurnal/jurnal baru/pemecahan masalah terbaru/marriyam (18).pdf. 1(1), 163-177.

Sugiyarti, L., Arif, A., \& Jakarta, U. N. (2018). Pembelajaran abad 21 di sd. 439-444.

Yustianingsih, R., \& Syarifuddin, H. (2017). Pengembangan Perangkat Pembelajaran Matematika Berbasis Problem Based Learning ( Pbl ) Untuk Meningkatkan Kemampuan Pemecahan Masalah. 1(2), 258-274. 